DOI: 10.17707/AgricultForest.61.3.03

\author{
Branimir URLIĆ, \\ Marko RUNJIĆ, Gvozden DUMIČIĆ ${ }^{1}$
}

\title{
OLIVE-MILL WASTE COMPOST AS A PEAT SUBSTITUTE IN LEAFY VEGETABLES TRANSPLANTS PRODUCTION
}

\begin{abstract}
SUMMARY
Olive-mill waste compost (OMWC) has been added to soil as a fertilizer or used as peat substitute in ornamentals and vegetable transplants production. Therefore, this experiment was carried to evaluate OMWC as a peat substitute in production of broccoli, cabbage, cauliflower, kale, lettuce and endivie transplants. The OMWC was mixed with commercial peat substrate at rates of $0 \%, 25 \%, 50 \%$ and $75 \% \mathrm{v} / \mathrm{v}$. Some physical and chemical properties of growing media, as transplant shoot fresh and dry mass, leaf number and leaf area were studied. Water holding capacity decreased and bulk density increased with increasing compost percentage in media. Substrate EC decreased linearly with increasing compost percentage and was lower in growing media after growing period. $\mathrm{pH}$ was higher in growing media after transplants growing and was species-dependant. All morphological parameters showed lowest values in treatment when $75 \%$ compost was used for all species, but Brassica transplants differ in parameters at other compost percentages. Increasing percentage of OWMC in growing media decreased parameters of lettuce and especially endivie transplants. OMWC could be used as replacement for peat in growing media at a rate of $50 \%$ for Brassica and $25 \%$ for lettuce and endivie transplants in subirrigated production.
\end{abstract}

Key words: Brassica sp., lettuce, endivie, subirrigation

\section{INTRODUCTION}

The most used substrate for production of transplants and soilless plant cultivation is peat, alone or in mixture (Fascella, 2015). Peat, as non-renewable resource is mostly taken from the mines located in northern and central Europe and it increased use during last decades generate questions about rising costs and ${ }^{2}$ environmental constraints due to degradation of highly fragile wetlands ecosystems. EU policies support the use of peat substitutes with decision that «eco» labeled growing media should not contain any peat, encouraging processing and re-use of organic waste (EU commission, 2006).

Many studies tried to identify new alternatives for peat made from locally available waste material from agriculture or urban activities, used after composting, as green waste (Spiers and Fietje, 2000; Zhang et al., 2013),

\footnotetext{
${ }^{1}$ Branimir Urlić (corresponding author: branimir@krs.hr), Marko Runjić, Gvozden Dumičić, Institute for Adriatic Crops and Karst Reclamation, Split, CROATIA.

Note: The authors declare that they have no conflicts of interest. Authorship Form signed online.
} 
municipal solid waste and sewage sludge (Hererra et al., 2008; Cai et al., 2010), seagrass posidonia (Mininni et al., 2012) and olive-mill waste (Papafotiou et al., 2004; Ceglie et al., 2011).

Olive farming is a one of the major land use in countries around Mediterranean Sea covering five million hectares in the EU members, having important economic and environmental significance on regional scale. The olive oil industry generates large quantities of wastes products, especially olive mill cake by- product of three-phase oil extraction system. This by-product is potentially harmful for the environment, with the phytotoxic and antimicrobial properties due to high phenols and organic matter content (Gómez-Muñoz et al., 2012). Olive-mill waste composting has been identified as proper tool for lowering content of unwanted compounds after 12 months of composting (Baddi et al., 2004).

The lack of homogeneity of different types of compost, possible phytotoxicity, high salinity level or undesirable physical properties showed that total peat substitution can be problem so partial replacement can be better technical solution for vegetable transplant production (Mininni et al., 2012; Ceglie et al., 2011; Hererra et al., 2008).

The vegetable seedlings production relies almost all on soilless media (mostly peat), due to demand for uniform emergence and rapid growth to ensure efficient production. Seedlings production is very often located in olive growing areas due to favourable climatic conditions for open-field and greenhouse vegetable production. Therefore, composted olive-mill waste should be considered as accessible peat substitute, resulting also in proper disposal of waste harmful to environment.

Subirrigation is an alternative irrigation method increasingly used in last years by ebb and flow benches, flooded floors and flood channels where the water and fertilizer are applied to the bottom of the container. Subirrigation offers improved labor, water and fertilizer efficiency, although negative effect of accumulation of salts has been observed (Kang et al., 2004). The nutrient leaching from subirrigated containers is minimal, so fertilizer inputs can be lowered (Liu et al., 2012).

The main objectives of the present study were 1.) To evaluate some chemical and physical properties of growing media obtained by mixing olive-mill waste compost and peat in different ratios and 2.) To identify the use of these substrates for production of kale, broccoli, cabbage, cauliflower, lettuce and endivie seedlings production with ebb-and-flow subirrigation.

\section{MATERIAL AND METHODS}

Plant material and experimental set-up. Experiment with leafy vegetables seedlings was conducted in unheated greenhouse at the Institute for Adriatic Crops at Split $\left(43^{\circ} 30^{\prime} 17^{\prime \prime} \mathrm{N}, 16^{\circ} 29^{\prime} 49^{\prime \prime E}\right)$ in the Mediterranean area of Croatia. Automatic ventilation was activated at $22^{\circ} \mathrm{C}$. 
Six different species were used, broccoli (Brassica oleracea var. italica) cv. Lucky F1; cauliflower (Brassica oleracea var. botrytis) cv. Fargo F1; cabbage (Brassica oleracea var. capitata) cv. Farao F1 (all suplied by Bejo Zaden, Netherlands), kale (Brassica oleracea var. acephala) local Croatian ecotype Pula (from Institute seed bank), lettuce (Lactuca sativa var. capitata) cv. Ice queen and endivie (Cichorium endivia var. crispum) cv. Pancalieri (Mladen commerce, Croatia).

The growth media were prepared by mixing olive-mill waste compost (OMWC) and peat (P). Peat substrate (Brill Type 4, Brill Substrate, Germany) was a mix of different peat with added NPK fertilizer and comprise $225 \mathrm{mg} / \mathrm{L} \mathrm{N}$, $90 \mathrm{mg} / \mathrm{L} \mathrm{K}_{2} \mathrm{O}, 255 \mathrm{mg} / \mathrm{L} \mathrm{P}_{2} \mathrm{O}_{5}$. Peat had $\mathrm{pH} \mathrm{5,8}$ and 70-90\% of organic matter. The compost was prepared after three-phase extraction of olive oil by natural composting with no addition of fermentation additives and was more than 1 years old to alleviate possible phytotoxicity. OMWC was collected from the middle portion of windrow pile. Four OMWC: $\mathrm{P}$ growing media mixtures were prepared: C0 (0\% compost), C25 (25\% compost), C50 (50\% compost) and C75 (75\% compost).

The seeds of all species were sowed in polystyrene plug trays (60 cells per tray with volume of $52 \mathrm{ml}$ ) on 24th July, one seed per cell for Brassica species and 3-4 seeds for lettuce and endivie. After sowing, the seeds were cowered with thin layer of peat. After watering trays with Brassica seeds were left in experimental greenhouse for germination, while trays with lettuce and endivie were put in climate chamber at $20^{\circ} \mathrm{C}$ to overcome possible seed termodormancy. Few days after germination finished, lettuce and endivie were thinned to one seedling per cell.

Eighteen days after sowing plug trays with seedlings were put on the closed side tables and nutrient solution was provided by subirrigation flooding 2 times a day for 30 minutes. Nutrient solution was modified half-strength Hoagland solution consisting as follows: $2.5 \mathrm{mM} \mathrm{Ca}\left(\mathrm{NO}_{3}\right)_{2} \cdot 4 \mathrm{H}_{2} \mathrm{O}, 1 \mathrm{mM}$ $\mathrm{KH}_{2} \mathrm{PO}_{4}, 3.5 \mathrm{mM} \mathrm{NH}_{4} \mathrm{NO}_{3}, 0.5 \mathrm{mM} \mathrm{KNO}{ }_{3}, 1 \mathrm{mM} \mathrm{MgSO}_{4}, 10 \mu \mathrm{M} \mathrm{MnSO}_{4}, 4 \mu \mathrm{M}$ $\mathrm{ZnSO}_{4}, 5 \mu \mathrm{M} \mathrm{Na} \mathrm{B}_{4} \mathrm{O}_{7} \cdot 10 \mathrm{H}_{2} \mathrm{O}, 0.5 \mu \mathrm{M} \mathrm{CuSO}_{4}, 0.5 \mathrm{Na}_{2} \mathrm{MoO}_{4}$ and $35 \mu \mathrm{M} \mathrm{Fe}-$ EDTA. The solution was adjusted to $\mathrm{pH} 6-6.5$ using $0.1 \mathrm{M} \mathrm{H}_{2} \mathrm{SO}_{4}$. Nutrient solution was renewed two times a week.

Thirty two days after beginning the experiment, plants were harvested and immediately separated into shoots and roots and weighed to determine fresh mass (FM). Brassica sp. shoots were also divided on leaves and stems. Leaf area of each sample was measured $\left(\mathrm{cm}^{2}\right)$ with leaf area meter LI-3000 (LiCor, USA). Samples were oven dried at $70^{\circ} \mathrm{C}$ for $48 \mathrm{~h}$ to constant weigh and measured to get dry mass (DM). Specific leaf area (SLA) was got dividing leaf area by DM.

The substrate samples were analysed for $\mathrm{pH}(1: 5 \mathrm{w} / \mathrm{v}$ sample: water extract) using a $\mathrm{pH}$ probe and electrical conductivity (EC) $(1: 5 \mathrm{w} / \mathrm{v}$ sample: water extract) was determined using an electrical conductivity probe in supernatant after 1 hour rotary shaking. The physical properties of growing media bulk density (BD) and water-holding capacity (WHC) were tested according to the 
method presented by Verdonck and Gabriels (1992). To measure growing media WHC, $100 \mathrm{~cm}^{3}$ of each substrate was saturated with water and placed in a chamber with controlled conditions $\left(22^{\circ} \mathrm{C}\right)$ to monitor the changes of water holding ratios (water content per unit of medium, w:w) following the evaporation time (Cai, 2010).

The experiment was laid out in completely randomized design. The data were evaluated by ANOVA and means were compared using Tukey`s HSD test at $p<0.05$. The data were statistically analysed using StatView ver. 5.0 (SAS Institute, Cary, North Carolina, USA).

\section{RESULTS AND DISCUSSION}

Characteristics of growing media. Increasing OMWC percentage in the growing media decreased water holding capacity (WHC) keeping it in an ideal range of $55-70 \%$ just for $\mathrm{C} 0$ and $\mathrm{C} 25$ treatments (Figure 1) and bulk density (BD) increased slightly with addition of OMWC (data not shown). Changes in WHC of media following evaporation time in growing chamber showed that $\mathrm{C} 0$ kept it in ideal range for almost 3 days, while for C25 fall under it immediately next day. These findings underline importance of proper irrigation management depending on growing media used. Media with $50 \%$ and $75 \%$ peat replacement held less water at saturation, but loose water slower compared to other two treatments. Although total porosity was not measured in our experiment, it seems that OWMC addition resulted in low total porosity and more micro pores, as was found by Papafotiou et al. (2005).

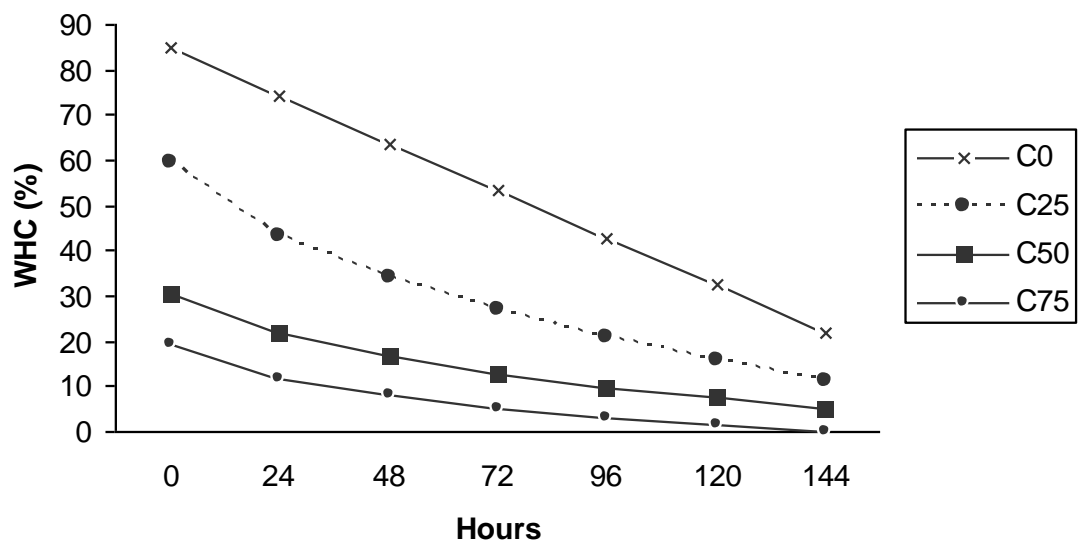

Figure 1: Changes in water holding capacity of growing media mixtures following evaporation time in the growing chamber.

The chemical properties of peat and substrate mixtures before and after growing of endivie, lettuce and broccoli are reported in Table 1. The substrate EC decreased linearly with increasing compost percentage and values were lower in growing media after growing of three transplant species. Although 
conventional thought is that subirrigation promotes the accumulation of excess salts in substrate, this was not confirmed by our data and it seems that subirrigation even lower EC after growing. Lettuce and endivie EC values were lower when compost was used and was near or below $0.5 \mathrm{dS} / \mathrm{m}$ proposed as a limit for ideal growing media (Abad et al., 2001). Ceglie at al. (2011) found EC increase due to more OMWC used in substrate mixture so our contrary data could be result of leaching of salts from composting pile due to prolonged storage of compost on open field.

$\mathrm{pH}$ was higher in growing media after transplants growing and differ between species. Lettuce and endivie $\mathrm{pH}$ values were highest at $50 \%$ and for broccoli at $75 \%$ peat replacement used. Higher $\mathrm{pH}$ in growing media after transplants growth could be influenced by accumulation of $\mathrm{Ca}$ and $\mathrm{Mg}$ from nutrient solution and not by higher content of these elements in compost as was proposed by Mininni et al. (2012) for posidonia based compost what was in our case confirmed by small $\mathrm{pH}$ differences in fresh prepared growing mixtures. However, the $\mathrm{pH}$ of the growing mixtures with the increasing OMWC was not so high to affect negatively growth compared to control.

Plant growth. In general, all Brassica transplants showed significant differences in FM, with lowest values in C75 treatment, while differences were not found between other treatments (data not shown).

Regarding other morphological characteristics (DM, leaf number, leaf area and SLA) data are shown in Figure 2. In general, similar to FM all parameters showed lowest values at $\mathrm{C} 75$ treatment. In broccoli transplants leaf number and SLA were reduced at the highest level and DW and leaf area were reduced also at $50 \%$ peat replacement by OMWC. Cauliflower DM, leaf area and SLA were decreased only at $75 \%$ peat replaced by OMWC, while leaf number was not affected by any treatment. Cabbage transplants grown in the media with $75 \%$ peat replacement by OWMC only differ from other treatments showing lowest values of all measured characteristics. In kale, all noted characteristics except SLA were not significantly affected even by highest OWMC level.

The percentage of compost used in growing media influenced significantly almost all measured lettuce and endivie transplant parameters apart SLA (data not shown), as reported in Table 2. In general, with increasing percentage of OWMC in growing media measured parameters decreased and that was especially pronounced in endivie transplants.

Soundy and Cantliffe (2001) growing lettuce transplants with different N rates in flotation systems showed that bigger ones lead later to earliness and improved head mass at harvest. Promoted growth in growing mixtures with less OMVC percentage can be result of higher water holding capacity or in our study subirrigated nutrient solution that supply transplants with more nutrients in prolonged period. As was shown by Liu et al. (2012) subirrigated kale and lettuce had shown increase in shoot FW and DW with increasing $\mathrm{N}$ concentrations suggesting increased fertilizer use efficiency. 

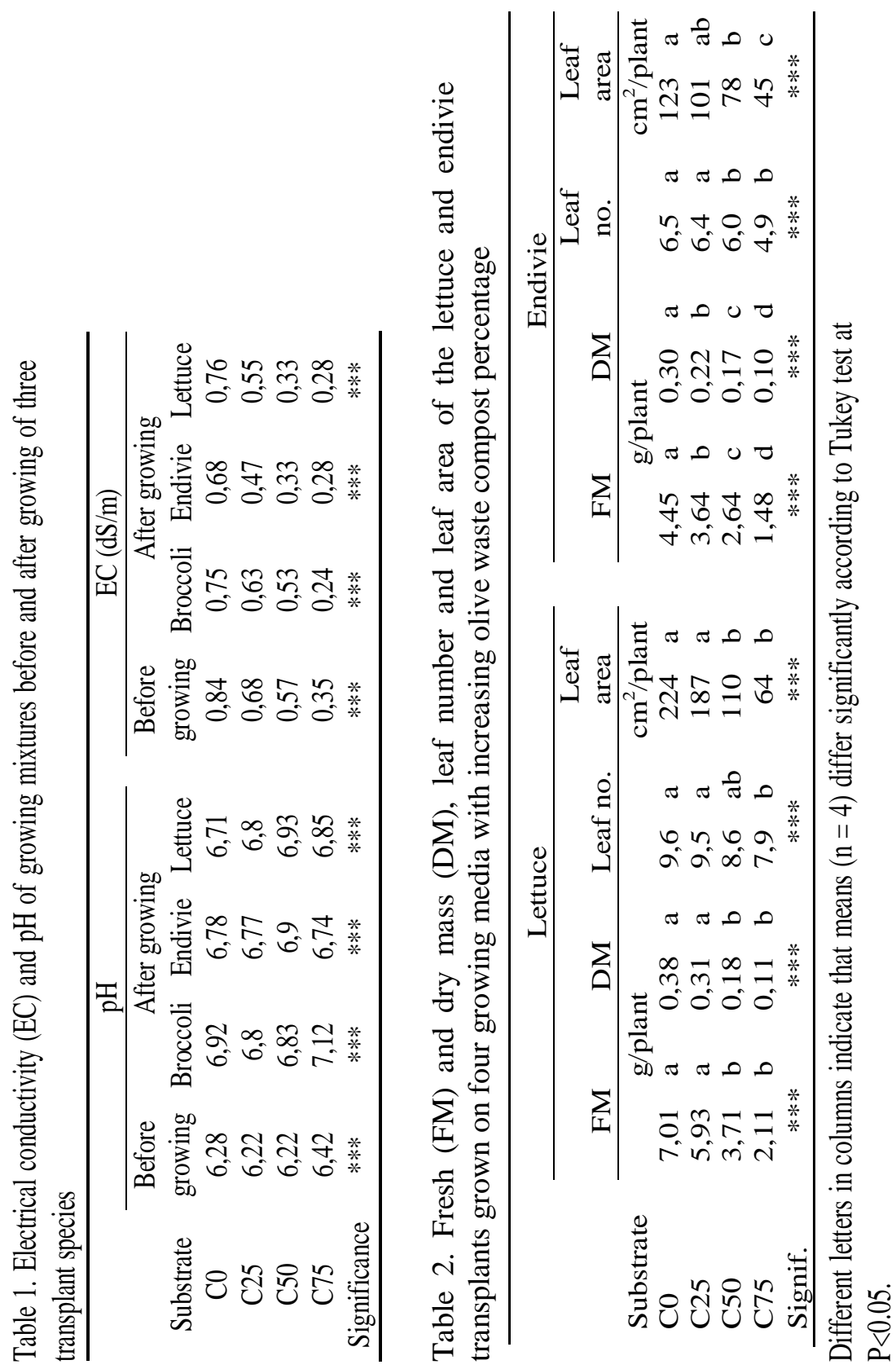

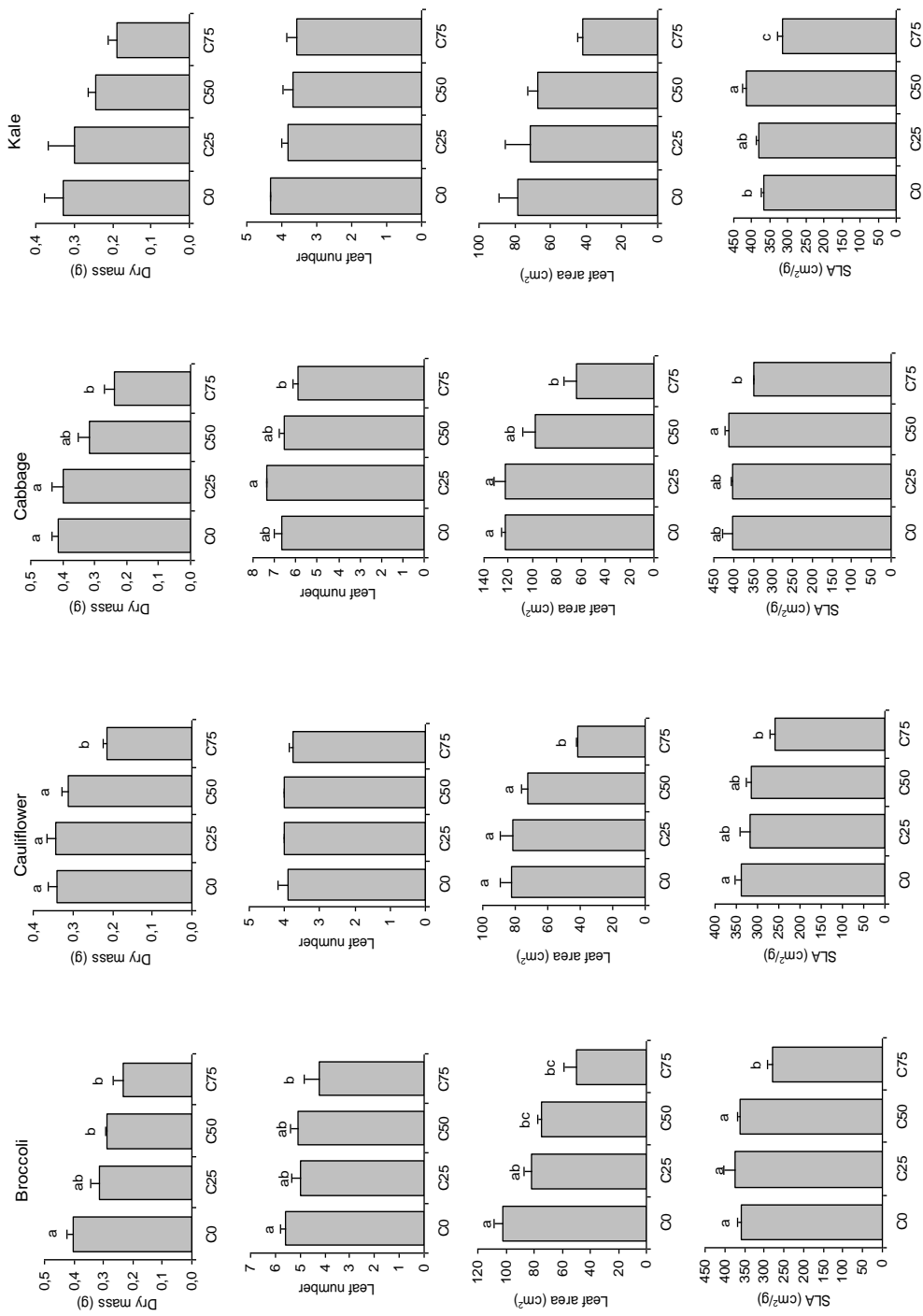

Figure 2: The effect of peat replacement by OMWC on measured growth parameters of four Brassica vegetable transplants. Different letters in graph indicate that means differing significantly according to Tukey test at $\mathrm{P}<0.05$.

The vertical bars indicate $\pm \mathrm{SE}$ of the means $(\mathrm{n}=3)$.

\section{CONCLUSIONS}

The present study showed that OMWC can replace $50 \%$ and $25 \%$ of peat used for Brassica and lettuce/enidivie transplants subirrigated production respectively without influencing transplant characteristics important for marketability. It should be pay special attention on irrigation management due to different water holding capacities of growing mixtures used. Replacement of peat in this way can contribute to environment protection and cost reduction. 


\section{REFERENCES}

Abad, M., Noguera, P. \& Bures, S. (2001): National inventory of organic wastes for use as growing media for ornamental potted plant production: Case study in Spain. Bioresource Technol., 77: 197-200

Baddi, G.A., Alburquerque, J.A., Gonzálvez, J., Cegarra, J. \& Hafidi, M. (2004): Chemical and spectroscopic analyses of organic matter transformations during composting of olive mill wastes. Int. Biodeter. Biodegr., 54: 39-44.

Cai, H., Chen, T., Liu, H., Gao, D., Zheng, G. \& Zhang, J. (2010): The effect of salinity and porosity of sewage sludge compost on the growth of vegetable seedlings. Sci. Hortic., 124: 381-386.

Ceglie, F.G., Elshafie, H., Verrastro, V. \& Tittarelli F. (2011): Evaluation of olive pomace and green waste composts as peat substitutes for organic tomato seedling production. Compost Sci. Util., 19(4): 293-300.

EU Commission. (2006): Commission Decision of 3 Nov. 2006 establishing revised ecological criteria and the related assessment and verification requirements for the award of the Community eco-label to growing media (2006/799/EC). Official Journal of the European Communities, L 325/28-L 325/34.

Fascella, G. (2015): Growing Substrates Alternative to Peat for Ornamental Plants. In Md. Asaduzzaman, ed. Soilless Culture - Use of Substrates for the Production of Quality Horticultural Crops, pp. 47 - 67. Rijeka, Croatia, INTECH Open Access Publisher.

Gómez-Muñoz, B., Hatch, D.J., García-Ruiz, R., \& Bol, R. (2012): The Compost of Olive Mill Pomace: From a Waste to a Resource-Environmental Benefits of Its Application in Olive Oil Groves. In S.Curkovic, ed. Sustainable Development - Authoritative and Leading Edge Content for Environmental Management s, pp. 459 - 484. Rijeka, Croatia INTECH Open Access Publisher.

Herrera, F., Castillo, J.E., Chica, A.F. \& Bellido, L.L. (2008). Use of municipal solid waste compost (MSWC) as a growing medium in the nursery production of tomato plants. Bioresource Technol., 99(2): 287-296.

Kang, J.G., van Iersel, M.W. \& Nemali, K.S. (2004): Fertilizer concentration and irrigation method affect growth and fruiting of ornamental pepper. J. Plant Nutr. 27: 867-884

Liu, J., Leatherwood, W. R. \& Mattson, N.S. (2012): Irrigation method and fertilizer concentration differentially alter growth of vegetable transplants. HortTechnology, 22(1): 56-63.

Mininni, C., Santamaria, P., Abdelrahman, H. M., Cocozza, C., Miano, T., Montesano, F. \& Parente, A. (2012): Posidonia-based compost as a peat substitute for lettuce transplant production. HortScience, 47(10): 1438-1444.

Papafotiou, M., Phsyhalou, M., Kargas, G., Chatzipavlidis, I. \& Chronopoulos, J. (2004): Olive-mill wastes compost as growing medium component for the production of poinsettia. Sci. Hortic., 102(2): 167-175.

Papafotiou, M., Kargas, G., \& Lytra, I. (2005): Olive-mill waste compost as a growth medium component for foliage potted plants. HortScience, 40(6): 1746-1750.

Soundy, P. \& Cantliffe, D.J. (2001): Improving lettuce transplant quality in response to nitrogen nutrition in a floatation production system. Proc. Fla. State Hort. Soc., 114: 294 303.

Spiers, T. M. \& Fietje, G. (2000): Green waste compost as a component in soilless growing media. Compost Sci. Util., 8(1): 19-23.

Verdonck, O. \& Gabriels, R. (1992): Reference method for determination of physical properties of plant substrates. Acta Hortic. 302: 169-179.

Zhang, L., Sun, X., Tian, Y. \& Gong, X. (2013): Composted green waste as a substitute for peat in growth media: effects on growth and nutrition of Calathea insignis. PloS one, 8(10): e78121. 